(1)

George Fox

UNIVERSITY
Digital Commons @ George Fox University

Faculty Publications - Doctor of Psychology (PsyD) Program

Doctor of Psychology (PsyD) Program

2020

Attitudes of Religious Leaders Toward Integrating Psychology and Church Ministry

Adam S. Hodge

Joshua N. Hook

Don E. Davis

Mark R. McMinn

Follow this and additional works at: https://digitalcommons.georgefox.edu/gscp_fac

Part of the Psychology Commons 


\title{
Attitudes of Religious Leaders Toward Integrating Psychology and Church Ministry
}

\author{
Adam S. Hodge and Joshua N. Hook \\ University of North Texas
}

\author{
Don E. Davis \\ Georgia State University
}

\author{
Mark R. McMinn \\ George Fox University
}

\begin{abstract}
Although psychology and religion deal with overlapping subject matter, the relationship between psychology and the church has a tumultuous history. The current study examined religious leaders' attitudes toward integrating psychological science into church ministry. Religious leaders $(N=394)$ completed measures of (a) congregants' mental health and social concerns, (b) attitudes toward psychological science (i.e., perceived barriers of integration, compatibility with church ministry), and (c) hypothesized predictors of attitudes toward the integration of psychology and church ministry (i.e., political conservatism, intratextual fundamentalism, religious intellectual humility, emotional intelligence). Overall, religious leaders expressed both positive and negative attitudes toward psychology. Conservative political orientation and intratextual fundamentalism were associated with negative attitudes toward integration, whereas religious intellectual humility and emotional intelligence were associated with positive attitudes. We conclude by discussing limitations, suggestions for future research, and practical applications for psychologists and church leaders.
\end{abstract}

Keywords: barriers, compatibility, experience (religion) - Christianity, integration, psychology and religion

Applied psychology and church ministry share several goals, such as (a) alleviating human suffering, (b) addressing social problems, and (c) promoting human flourishing. Religious leaders are also often a first point of contact

This article was published Online First June 13, 2019.

Adam S. Hodge and Joshua N. Hook, Department of Psychology, University of North Texas; Don E. Davis, Department of Counseling and Psychological Services, Georgia State University; Mark R. McMinn, Graduate Department of Clinical Psychology, George Fox University.

This research was supported by a grant from the John Templeton Foundation (Grant 60465). The opinions expressed in this publication are those of the authors and do not necessarily reflect the views of the John Templeton Foundation.

Correspondence concerning this article should be addressed to Adam S. Hodge, Department of Psychology, University of North Texas, 1155 Union Circle \#311277, Denton, TX 76203. E-mail: adamhodge@my.unt.edu when religious individuals experience mental health problems, and many churches offer programs and support ministries to help congregants with psychological and relational difficulties. Given this substantial overlap, and because many psychologists are engaged within local churches and religious professional organizations, one might expect a long history of work partnership between psychology and church leaders. Unfortunately, this has not generally been the case. Instead, the relationship between psychology and the church has a tumultuous history. These two communities have operated mostly in separate domains and have at times been overtly antagonistic toward one another. In the present study, we conducted a survey of religious leaders to assess their attitudes toward integrating psychology and church ministry. We used these findings to consider potential next steps for collaboration and work in this area. 


\section{Psychology, Religion, and Spirituality}

Applied psychology has largely operated independently of religion and church life. Many of the founding fathers of psychology questioned the value of religion or criticized it as harmful (e.g., Freud, 1927/1961; Skinner, 1953), whereas others had more positive and hopeful views of religion (James, 1902/1985; Jung, 1954/1968). Even so, much of the literature and practice of applied psychology did not seriously consider religious considerations for the majority of the 20th century. This distance may have occurred because psychologists tended to be less religious than the general population whom they served (Shafranske \& Malony, 1990; Walker, Gorsuch, Tan, \& Otis, 2008).

Although psychologists remain less religious than the general public (Delaney, Miller, \& Bisono, 2013), the general attitudes of psychologists toward religion and spirituality appeared to shift and become more positive toward the end of the 20th century. There were two primary reasons for this shift in attitudes. First, research began to accumulate showing that religion and spirituality played a role in helping individuals attain positive physical and mental health outcomes (Koenig, King, \& Carson, 2012; Miller \& Thoresen, 2003). Because of this research, psychologists began to view religion and spirituality as a resource or source of support that people could turn to in times of difficulty or trouble. Also, religion and spirituality began to be viewed as a protective factor for preventing physical and mental illness.

The second reason for this shift was an increased valuing of diversity, as well as a broadening of the kinds of identities that deserved respect under the multicultural umbrella. In the 1970s and 1980s, psychologists began to recognize that racial/ethnic minorities were not getting their needs met in counseling. This realization led to a series of articles that outlined what it meant to be multiculturally competent with diverse clients (Sue, Arredondo, \& McDavis, 1992; Sue et al., 1982). At first, the multicultural counseling movement focused primarily on race/ethnicity. However, as the movement grew and developed, it expanded to include other aspects of diversity (Cornish, Schreier, Nadkarni, Metzger, \& Rodolfa, 2010), includ- ing religion and spirituality (Hook, Worthington, \& Davis, 2012).

These shifts have led to an increase in psychological research on religion and spirituality in recent years. For example, there are now several organizations that focus on psychological research of religion and spirituality (e.g., Christian Association of Psychological Studies; Division 36 of APA: Society for the Psychology of Religion and Spirituality). The APA journal Psychology of Religion and Spirituality was launched in 2009 (Piedmont, 2009), and another APA journal, Spirituality in Clinical Practice, started in 2014. With this increased research and clinical focus on religious and spiritual issues in therapy, the research base on adapting interventions to the client's religious or spiritual identity expanded rapidly (Captari et al., 2018; Hook et al., 2010).

Psychological science has also focused on several issues that have the potential to be important to Christian church leaders and church ministry support groups. First, treatments for general mental health problems impact individuals' ability to experience a healthy spirituality. For example, interventions to treat depression might help individuals experience more joy in their lives; interventions to treat anxiety might help individuals experience more peace. Second, there have been a plethora of treatments that have been developed to help individuals experience healthy family relationships and marriages (Baucom, Shoham, Mueser, Daiuto, \& Stickle, 1998; Jakubowski, Milne, Brunner, \& Miller, 2004). Family relationships and the institution of marriage are considered to be of utmost importance in Christian churches, and many religious individuals use parenting or relational practices from their religion to inform parenting and relational behaviors. Third, the positive psychology movement, which began around the turn of the century (Seligman \& Csikszentmihalyi, 2000), accelerated the study of many virtues that are integral to Christian spirituality, such as work on forgiveness (Wade, Hoyt, Kidwell, \& Worthington, 2014), gratitude (Emmons \& McCullough, 2003), humility (Davis, Worthington, \& Hook, 2010), and selfcontrol (Baumeister \& Vohs, 2004).

Though several studies have explored how counseling or psychotherapy might be adapted to fit more closely with a client's religious or spiritual commitments, there has been relatively 
little work exploring how psychology or psychological research, such as the research mentioned previously, might be integrated into church ministry (see Benes, Walsh, McMinn, Dominguez, \& Aikins, 2000; McMinn, Meek, Canning, \& Pozzi, 2001, for notable exceptions). Given the large number of clients served by both Christian church leaders and psychologists, it is important to ease communication between these two helping professions in order to ensure continuity and coordination of treatment for people served by both groups.

\section{Church Ministry and Mental Health}

In a similar way that psychology has largely operated without the influence of religion and spirituality, the church has largely operated without the influence or awareness of psychological research. In principle, psychologists strive to base clinical interventions on established research (cf. Lilienfeld, 2007). The church has a long history of caring for people's emotional, relational, and spiritual needs (Yarhouse, McRay, \& Butman, 2016), but often without much attention to the research that may or may not support the interventions being offered. Religious leaders are often called on to assist congregants who struggle with a wide range of individual and interpersonal problems. Even if religious leaders do not personally conduct counseling with their congregants, they are often on the "front line" of mental health treatment (Kloos, Horneffer, \& Moore, 1995). When seeking help for a personal problem, many religious individuals prefer to seek the help of clergy first (Allen \& Hill, 2014; Veroff, Kulka, \& Douvan, 1981). For example, a survey of residents in El Paso, TX found that participants preferred to seek help from clergy at a higher rate $(41 \%)$ than both medical doctors $(29 \%)$ or psychiatrists/psychologists (21\%; Chalfant et al., 1990). Because of tendency of religious individuals to prioritize seeking help from clergy, Gorsuch and Meylink (1988) labeled clergy as the "gatekeepers" to the professional practice of psychology.

Many churches also offer a variety of what psychologists might consider psycho-educational interventions to address emotional and relational problems. For example, Celebrate Recovery is a popular religiously based 12-step program designed for individuals struggling with addiction issues and other personal problems (Brown, Tonigan, Pavlik, Kosten, \& Volk, 2013). Other common church-based support groups target issues such as marital discord (Hook, Worthington, Hook, Miller, \& Davis, 2011), divorce recovery (McCage, 2003), grief support (Thompson, 1988), and sexual addiction (Burford, 2005). Furthermore, following the lead of several megachurches, many communities use small groups as their primary mechanism of structuring the community of larger congregations (Hook, Hook, \& Davis, 2017). Being part of a small group has the potential to provide members a variety of coping resources. Thus, there is a ready-made infrastructure in many churches for disseminating psychological knowledge and interventions (Savage, 2003; Terry et al., 2015).

\section{Barriers Between Psychology and Church Ministry}

Research has revealed several barriers making it difficult to integrate psychology and church ministry. First, clergy may not be aware of potential opportunities to integrate psychology into their church ministry contexts. For example, the most common forms of collaboration between clergy and mental health professionals appear to be unidirectional and focus on clergy referring troubled parishioners to a mental health professional for therapy (Edwards, Lim, McMinn, \& Dominguez, 1999). In a study of 117 religious leaders, who were asked about their interest in various forms of potential collaboration, most only showed interest in making referrals, as opposed to other forms of potential collaboration (e.g., offering a workshop, providing consultation to address tension among pastoral staff members, etc.; Lish, McMinn, Fitzsimmons, \& Root, 2003). Clergy may think of psychologists mainly as individuals who accept referrals for mental health services.

Second, clergy may fear that collaborating with psychologists will introduce congregants to different types of values that would undermine the religious values of the church community. Psychologists tend to be more liberal than the general population (Inbar \& Lammers, 2012), and others have found that liberals and conservatives tend to use different moral foundations when making moral decisions (Graham, Haidt, \& Nosek, 2009). Specifically, individuals 
who are more liberal tend to make moral decisions based on the foundations of harm and fairness, whereas conservatives also consider the foundations of loyalty, authority, and purity. Regarding specific religious values, Chaddock and McMinn (1999) asked 56 evangelical Christian clergy and 81 psychologists about values that they viewed as important for effective collaboration with individuals from the other profession. Clergy and psychologists differed on the importance of several values; the largest differences were for the importance of shared evangelical values, regulated sexuality, religious/spiritual values, and forgiveness, with clergy rating each value as more important. So, perhaps clergy are hesitant to collaborate out of protectiveness of their congregations.

Third, clergy and psychologists may not trust one another (McMinn, Chaddock, Edwards, Lim, \& Campbell, 1998). This lack of trust may be accentuated to the degree that religious leaders ascribe to theologically or politically conservative values and traditions. Many psychologists ascribe to social justice values that view social structures as often causing harm to individuals (Vera \& Speight, 2003). Thus, this difference in how psychologists and clergy may view the authority of the church and religious leadership has the potential to threaten productive collaboration. Although the problem of trust between these two fields has been noted in previous research (e.g., Kloos et al., 1995; Newberry \& Tyler, 1997), relatively little research has been done to outline the specific areas that may impede trust between church leaders and psychologists.

\section{Predictors of Attitudes Toward Psychology}

Several variables may impact church leaders' attitudes regarding the integration of psychology and church ministry. First, research on politics and religion has recognized the importance of religion in predicting political values and voting trends (Wilde \& Glassman, 2016), as well as moral decision making (Johnson et al., 2016). Religion and politics are closely intertwined in the United States. Psychology is often viewed as a more liberal field of study, especially with the emphasis on social justice in recent years (Duarte et al., 2015). Thus, it may be that more conservative religious leaders have more negative attitudes about integrating psy- chology into church ministry. Related to this point, religious denomination might impact attitudes toward psychology because of their conservative or liberal political leanings. Mainline protestant denominations (i.e., denominations that are associated with the National Council of Churches and have historic roots and influence in American society; Hadaway \& Marler, 2006) have historically been viewed as more liberal; thus, mainline protestant religious leaders may have more positive views toward integration of psychology and church ministry than evangelical protestant (i.e., an umbrella group of protestant churches that affirm the doctrine of being regenerated, emphasize evangelism, and affirm the authority and historicity of the Bible; FitzGerald, 2017) or catholic religious leaders.

Second, intratextual fundamentalism, which gives centrality to a sacred text as the sole source of truth (Hood, Hill, \& Williamson, 2005), may also be a significant contributor to attitudes about the integration of psychology and church ministry. Barr (1977) explains that American Protestant fundamentalism began as a reaction against modernism (e.g., the theory of evolution). Thus, individuals who score high on intratextual fundamentalism (and view the Bible as the sole source of truth) may not be as open to findings from psychology that are deemed secular.

Third, intellectual humility involves being aware of the limitations of one's perspective and openness to new and different points of view (Hook et al., 2015). Humble individuals are able to regulate their concern about being right and are open to new information. Religion and humility may have a paradoxical relationship. Although Christianity (and most religions) view humility as a virtue, it may be difficult to be humble about one's own religious convictions (Woodruff, Van Tongeren, McElroy, Davis, \& Hook, 2014). Thus, religious leaders who are more intellectually humble may be more open to information (such as psychology) that is outside of one's religious perspective.

Fourth, emotional intelligence involves one's ability to reason through emotions and use emotions to enhance their thoughts (Mayer, Roberts, $\&$ Barsade, 2008). Church leaders who are more emotionally intelligent are likely to prioritize mental health and view it as more important for congregants. Thus, it may be that religious leaders who are more emotionally intelligent are 
more open to integrating psychology into their church ministry. Randall (2014) suggests that many people are drawn toward priesthood because of an interest in theology and the church, and also that theological colleges and institutions emphasize academic studies over interpersonal and emotional intelligence. These characteristics may decrease the value, or importance, that church leaders place on psychology as psychology simply may not be of interest to the leaders.

\section{The Present Study}

The current study investigated the attitudes of religious leaders toward integrating psychology into church ministry. We had three main research questions. First, we assessed the prevalence of various mental health/relational and social/community concerns in one's congregation. In other words, what psychological problems are religious leaders seeing in their congregants? We also tested whether there were differences in perceived prevalence of psychological problems based on denomination (i.e., evangelical protestant, mainline protestant, catholic), although we did not have a specific hypothesis about denominational differences.

Second, we asked about religious leaders' perceptions of potential barriers that stopped them from integrating psychology and church ministry. We hypothesized that mainline protestant religious leaders would perceive fewer barriers to integration compared with catholic and evangelical protestant religious leaders. Additionally, we hypothesized that political conservatism and intratextual fundamentalism would be positively associated with perceived barriers, whereas intellectual humility and emotional intelligence would be negatively associated with perceived barriers.

Third, we explored religious leaders' perceptions of the compatibility between psychology and church ministry. Specifically, we hypothesized that mainline protestant religious leaders would have more favorable views of compatibility compared with catholic and evangelical protestant religious leaders. Furthermore, we expected that political conservatism and intratextual fundamentalism would be negatively associated with perceived compatibility, whereas we hypothesized that intellectual humility and emotional intelligence would be positively associated with perceived compatibility.

\section{Method}

\section{Participants}

Participants were 394 church leaders (371 male, 23 female), who held a full-time paid position in their congregation. Participants ranged in age from 25 to 77 years $(M=51.07$, $S D=11.05)$. Participants primarily identified as white $(94.5 \% ; 2.2 \%$ Black/African American, $1.7 \%$ Asian, $1.5 \%$ Hispanic/Latinx, .7\% Other). The ethnic makeup of the participants' churches was also primarily white (86.3\%; $3.0 \%$ Hispanic/Latinx, $1.8 \%$ Black/African American, $0.8 \%$ Asian, $0.3 \%$ American Indian/ Alaska Native, $7.6 \%$ Multiracial $0.3 \%$ Other). Regarding religious identification, all participants identified as Christian. Participants identified their specific religious denomination and these denominations were coalesced into three broad denominations: (a) Evangelical Protestant, (b) Mainline Protestant, and (c) Catholic. Regarding broad denomination, $53.8 \%$ of participants identified as Evangelical Protestant, $21.6 \%$ identified as Mainline Protestant, and $24.6 \%$ identified as Catholic. The majority of participants reported that they had obtained a master's degree $(64.6 \% ; 19.7 \%$ doctoral degree, $10.5 \%$ bachelor's degree, $2.5 \%$ some college, $2.2 \%$ associates degree, . $5 \%$ high school diploma or GED). One hundred forty-six participants reported descriptions of their church location. Of these 146 participants, 33.6\% described their church as being located in a suburban/town area, $30.8 \%$ described their church as being located in an urban/city area, $21.9 \%$ described their church as being located in a small town, and $13.7 \%$ described their church as being located in a rural area.

\section{Measures}

Prevalence of mental health and relational concerns. Participants completed 23 items that assessed the prevalence of various mental health concerns (e.g., depression, anxiety) and relational concerns (e.g., empty nest issues, unforgiveness) the participant observed in their ministry. Participants rated each item on a 5-point rating scale ranging from 1 (not at all 
common) to 5 (very common). We calculated the mean of the 23 items, with higher values indicating a higher prevalence of mental health and relational concerns. In the current sample, the Cronbach's alpha was .90 .

Prevalence of social and community concerns. Participants completed 17 items that assessed the prevalence of social or community concerns (e.g., poverty, racism) the participant observed in their ministry. Participants rated each item on a 5-point rating scale ranging from 1 (not at all common) to 5 (very common). We calculated the mean of these 17 items, with higher values indicating a higher prevalence of social and community concerns. In the current sample, the Cronbach's alpha was .84.

Perceived barriers to integrating psychological science and church ministry. Participants completed nine items that assessed the degree to which various barriers were perceived to hinder the participant from integrating psychological science in their ministry. Specifically, participants reported their perception of nine distinct barriers: (a) too busy, (b) lack of resources/funds, (c) not relevant to church's mission, (d) need further training or information in this area, (e) worldview differences, (f) value conflicts, (g) incompatibility with church's theological beliefs, (h) lack of biblical credibility, and (i) caution about potential secular/ humanistic influence. Participants rated each item on a 5-point rating scale ranging from 1 (not a barrier) to 5 (very high barrier). We calculated the mean of the nine items, with higher values indicating higher levels of perceived barriers. In the current sample, the Cronbach's alpha was .82 .

Compatibility of psychological science and church ministry. Participants completed seven items that measured the extent to which they believed that psychological science and Christian ministry were compatible. Specifically, participants reported the extent to which psychological science was compatible with seven aspects of Christian ministry: (a) beliefs about God, (b) beliefs about the Bible, (c) beliefs about human nature, (d) values, (e) morals, (f) goals of Christian ministry, and (g) goals of spiritual care. Participants rated each item on a 5-point rating scale from 1 (not at all compatible) to 5 (extremely compatible). We calculated the mean of the seven items, with higher scores indicating higher levels of compatibility be- tween psychological science and church ministry. In the current sample, the Cronbach's alpha was .93 .

Political views. Participants completed three items that assessed political views. The three items measured the degree to which the participant held a conservative or liberal view on (a) foreign policy issues, (b) economic issues, and (c) social issues. Participants rated each item on a 7-point rating scale ranging from 1 (very liberal) to 7 (very conservative). We calculated the mean of the three items, with higher values indicating higher levels of conservativism. In the current sample, the Cronbach's alpha was .89 .

Intratextual fundamentalism. Participants completed the Intratextual Fundamentalism Scale (IFS; Williamson, Hood, Ahmad, Sadiq, \& Hill, 2010). The IFS has five items that measure the tendency to (a) accept a sacred text as the sole foundation of objective truth and (b) describe the interpretive process through which the objective truth from the text is derived (e.g., "The Bible should never be doubted, even when scientific or historical evidence outright disagrees with it"). Participants rated each item on a 6-point rating scale ranging from 1 (strongly disagree) to 6 (strongly agree). Williamson et al. (2010) reported that the IFS had good internal consistency, and it was significantly associated with right wing authoritarianism and frequency of attendance at church/religious meetings. We calculated the mean of the five items, with higher scores indicating higher levels of intratextual fundamentalism. In the current sample, the Cronbach's alpha was .74.

Religious intellectual humility. Participants completed a modified version of the Cultural Humility Scale (CHS; Hook, Davis, Owen, Worthington, \& Utsey, 2013; Hook et al., 2015) to assess religious intellectual humility. The scale has 12 items (e.g., "Regarding different types of religious beliefs and values, I am genuinely interested in learning more"). Participants rated each item on a 5-point rating scale ranging from 1 (strongly disagree) to 5 (strongly agree). Hook et al. (2015) reported that this modified version of the cultural humility scale for religious beliefs/values had high levels of internal consistency and was significantly associated with other measures of humility. We calculated the mean of the 12 items, with higher scores indicating higher levels of 
religious intellectual humility. In the current sample, the Cronbach's alpha was .69 which represents marginal reliability.

Emotional intelligence. Participants completed the short form version of the Trait Emotional Intelligence Questionnaire (TEIQ-SF; Petrides, 2009). The TEIQ-SF has 30 items that measure emotional intelligence (e.g., "I'm usually able to find ways to control my emotions when I want to"). Participants rated each item on a 7-point rating scale ranging from 1 (strongly disagree) to 7 (strongly agree). Cooper and Petrides (2010) found the TEIQ-SF to have high levels of internal consistency. Research has shown that the TEIQ-SF continues to follow the theoretically established fourfactor structure of emotional intelligence (Laborde, Allen, \& Guillén, 2016). We calculated the mean of the 30 items, with higher scores indicating higher levels of emotional intelligence. In the current sample, the Cronbach's alpha was .89 .

\section{Procedure}

This research project was approved by the university institutional review board. Participants were recruited through a research company (i.e., Barna Group) that focuses on the intersection of religious faith and culture. Protestant religious leaders were identified through Barna Panel and Catholic leaders were identified through InfoUSA. Participants were sent a survey invitation via e-mail that explained the general purpose and expectations of the survey, along with a link to access the online survey. Participants had to identify as Priests, Senior Pastors, Executive Pastors, or Associate Pastors and hold a full-time position at their church to participate in the study. Participants who were interested in completing the survey indicated informed consent and filled out a series of online questionnaires. Of the 2,715 requests sent to protestant religious leaders, 306 leaders (11\%) completed the survey. There were no protestant leaders who logged into the survey and declined to participate. Of the 4,492 e-mail requests sent to Catholic leaders, 93 leaders (2\%) completed the survey; however, two of these leaders were identified through the Barna Panel. Eight of the 167 Catholic leaders that logged into the survey and declined to participate. Upon completion of the survey, participants were directed to a debriefing page that provided the contact information of the principal investigator in case they had questions or concerns regarding the study. Participants received a $\$ 50$ gift card as compensation for their participation in the study.

\section{Results}

Means, standard deviations, and intercorrelations for study variables are in Table 1 . Regarding attitudes toward psychology, the pattern of correlations showed a consistent pattern. Perceived barriers were positively correlated with political conservatism and intratextual fundamentalism, and negatively correlated with religious intellectual humility and emotional intelligence. Compatibility, on the other hand, was negatively correlated with political conservatism and intratextual fundamentalism, positively correlated with religious intellectual humility, and uncorrelated with emotional intelligence. Differences observed across mainline protestant, evangelical protestant, and cath-

Table 1

Means, Standard Deviations, and Intercorrelations Among Study Variables

\begin{tabular}{|c|c|c|c|c|c|c|c|c|c|c|}
\hline Measure & $M$ & $S D$ & 1 & 2 & 3 & 4 & 5 & 6 & 7 & 8 \\
\hline 1. Mental health/relational concerns & 3.56 & 0.59 & - & & & & & & & \\
\hline 2. Social/community concerns & 3.56 & 0.61 & $.66^{* *}$ & - & & & & & & \\
\hline 3. Barriers & 3.03 & 0.81 & .06 & -.05 & - & & & & & \\
\hline 4. Compatibility & 3.75 & 0.93 & $.17^{* *}$ & $.26^{* * *}$ & $-.33^{* *}$ & - & & & & \\
\hline 5. Political conservatism & 3.45 & 1.12 & -.06 & $-.27^{* * *}$ & $.55^{* *}$ & $-.38^{* *}$ & - & & & \\
\hline 6. Intratextual fundamentalism & 4.60 & 1.22 & -.02 & $-.15^{* *}$ & $.55^{* *}$ & $-.39^{* * *}$ & $.71^{* * *}$ & - & & \\
\hline 7. Religious intellectual humility & 3.94 & 0.45 & .02 & .06 & $-.23^{* *}$ & $.16^{* *}$ & $-.23^{* *}$ & $-.29^{* * *}$ & - & \\
\hline 8. Emotional intelligence & 5.41 & 0.62 & -.05 & -.07 & $-.10^{*}$ & .04 & .05 & -.03 & $.30^{* * *}$ & - \\
\hline
\end{tabular}

${ }^{*} p<.05 . \quad{ }^{* *} p<.01$. 
Table 2

Mean Differences for Study Variables Across Denominations

\begin{tabular}{llllr}
\hline \multicolumn{1}{c}{ Variable } & Mainline & Evangelical & Catholic & $F$ \\
\hline Mental health/relational concerns & $3.60(0.61)_{\mathrm{a}}$ & $3.53(0.58)_{\mathrm{a}}$ & $3.58(0.59)_{\mathrm{a}}$ & .48 \\
Social/community concerns & $3.77(0.61)_{\mathrm{a}}$ & $3.47(0.59)_{\mathrm{b}}$ & $3.59(0.59)_{\mathrm{a}} \mathrm{b}$ & 8.16 \\
Barriers & $2.67(0.77)_{\mathrm{a}}$ & $3.32(0.70)_{\mathrm{b}}$ & $2.73(0.83)_{\mathrm{a}}$ & $33.48^{* *}$ \\
Compatibility & $4.09(0.73)_{\mathrm{a}}$ & $3.46(0.98)_{\mathrm{b}}$ & $4.10(0.73)_{\mathrm{a}}$ & $25.58^{* * *}$ \\
Political conservatism & $2.54(1.06)_{\mathrm{a}}$ & $4.01(0.89)_{\mathrm{b}}$ & $3.03(0.88)_{\mathrm{c}}$ & $88.83^{* * *}$ \\
Intratextual fundamentalism & $3.74(1.21)_{\mathrm{a}}$ & $5.31(0.76)_{\mathrm{b}}$ & $3.80(1.04)_{\mathrm{a}}$ & $128.85^{* *}$ \\
Religious intellectual humility & $4.02(0.36)_{\mathrm{a}}$ & $3.86(0.45)_{\mathrm{b}}$ & $4.06(0.49)_{\mathrm{a}}$ & $7.89^{* *}$ \\
Emotional intelligence & $5.29(0.65)_{\mathrm{a}}$ & $5.42(0.60)_{\mathrm{a}}$ & $5.49(0.64)_{\mathrm{a}}$ & 2.29 \\
\hline
\end{tabular}

Note. Different subscripts are significantly different from each other at $p<.05$. Welch's $F$ statistic is provided for ANOVAs that did not meet the assumption of homogeneity of variance.

*** $p<.001$.

olic religious leaders for study variables are included in Table 2.

\section{Prevalence of Psychological Concerns}

Our first research question explored the prevalence of various mental health/relational concerns and social/community concerns that church leaders report experiencing in their congregation. (See Table 3 for means and standard deviations of mental health and relational concerns and Table 4 for means and standard deviations of social and community concerns.) The results indicated that both mental health/ relational concerns and social/community concerns are prevalent in Christian communities. Mental health and relational concerns $(M=$ 3.56; $S D=0.59$ ) were identified as somewhat commonly observed in the participants' congregations. Similarly, social and community concerns $(M=3.56 ; S D=0.61)$ were somewhat commonly observed in the participants' congregations.

We also tested whether there were differences in overall prevalence of (a) mental health/ relational concerns and (b) social/community concerns based on the church leader's denomination (i.e., evangelical protestant, mainline protestant, catholic). We used one-way analyses of variance (ANOVAs) with mental health/ relational and social/community concerns as the dependent variables and denomination as the independent variable. There was not a significant difference in mental health/relational concerns based on denomination, $F(2,391)=.62$, $p=.621$.

There was, however, a significant difference in social/community concerns based on denom- ination, $F(2,391)=8.16, p<.001$. Post hoc tests with a Tukey correction revealed that religious leaders from mainline protestant denominations reported higher levels of social/ community concerns $(M=3.77, S D=0.61)$ than did religious leaders from evangelical protestant denominations $(M=3.47, S D=0.59$; $p<.001)$. Religious leaders from catholic de-

Table 3

Prevalence of Mental Health/Relational Concerns

\begin{tabular}{ll}
\hline \multicolumn{1}{c}{ Concerns } & $M(S D)$ \\
\hline Grief and loss & $4.47(0.80)_{\mathrm{a}}$ \\
Anxiety & $4.39(0.89)_{\mathrm{a}}$ \\
Parenting challenges & $4.39(0.88)_{\mathrm{a}}$ \\
Unforgiveness & $4.27(0.96)_{\mathrm{b}}$ \\
Family conflict & $4.25(0.91)_{\mathrm{b}}$ \\
Depression & $4.24(0.91)_{\mathrm{b}}$ \\
Aging & $4.23(1.02)_{\mathrm{b}, \mathrm{c}}$ \\
Shame/Guilt & $4.21(0.95)_{\mathrm{b}, \mathrm{c}}$ \\
Marital distress & $4.14(0.90)_{\mathrm{c}}$ \\
Addiction & $3.96(1.03)_{\mathrm{d}}$ \\
Life transitions & $3.87(1.08)_{\mathrm{d}, \mathrm{e}}$ \\
Sexual issues (e.g., pornography, & \\
$\quad$ infidelity) & $3.87(1.20)_{\mathrm{d}, \mathrm{e}}$ \\
Sexual values & $3.80(1.18)_{\mathrm{e}}$ \\
Trauma & $3.23(1.15)_{\mathrm{f}}$ \\
Abuse & $3.14(1.17)_{\mathrm{f}}$ \\
Empty nest issues & $2.97(1.14)_{\mathrm{g}}$ \\
Special needs children & $2.92(1.10)_{\mathrm{g}}$ \\
Suicidal thoughts & $2.71(1.11)_{\mathrm{h}}$ \\
Domestic violence & $2.68(1.11)_{\mathrm{h}}$ \\
Sexual identity/Orientation issues & $2.63(1.14)_{\mathrm{h}}$ \\
Eating disorders & $2.63(1.16)_{\mathrm{h}, \mathrm{i}}$ \\
Severe mental illness (e.g., & \\
Schizophrenia, Bipolar) & $2.50(1.10)_{\mathrm{i}}$ \\
Self-Injury/Cutting & $2.36(1.16)_{\mathrm{j}}$ \\
\hline Note. Diffent &
\end{tabular}

Note. Different subscripts are significantly different from each other at $p<.05$. 
Table 4

Prevalence of Social/Community Concerns

\begin{tabular}{ll}
\hline \multicolumn{1}{c}{ Concerns } & $M(S D)$ \\
\hline Sin & $4.62(0.77)_{\mathrm{a}}$ \\
Need for stronger families & $4.49(0.81)_{\mathrm{b}}$ \\
Materialism & $4.41(0.86)_{\mathrm{b}}$ \\
Lack of responsibility/immaturity & $4.05(0.98)_{\mathrm{c}}$ \\
Secularism & $3.98(1.13)_{\mathrm{c}, \mathrm{d}}$ \\
Greed & $3.85(1.11)_{\mathrm{d}, \mathrm{e}}$ \\
Political division & $3.84(1.17)_{\mathrm{d}, \mathrm{e}}$ \\
Sexual immorality & $3.83(1.12)_{\mathrm{e}}$ \\
Poverty & $3.58(1.21)_{\mathrm{f}}$ \\
Capitalism & $3.50(1.47)_{\mathrm{f}, \mathrm{g}}$ \\
Unemployment & $3.36(1.10)_{\mathrm{g}}$ \\
Racism & $3.17(1.24)_{\mathrm{h}}$ \\
Sexism & $2.94(1.26)_{\mathrm{i}}$ \\
Intolerance of gender and sexual & \\
$\quad$ minorities & $2.90(1.26)_{\mathrm{i}}$ \\
Homelessness & $2.86(1.21)_{\mathrm{i}}$ \\
Religious intolerance & $2.85(1.24)_{\mathrm{i}}$ \\
Needs of refuges & $2.32(1.23)_{\mathrm{j}}$ \\
\hline
\end{tabular}

Note. Different subscripts are significantly different from each other at $p<.05$.

nominations $(M=3.59, S D=0.59)$ did not significantly differ from mainline protestant $(p=.086)$ or evangelical protestant religious leaders $(p=.233)$.

\section{Barriers to Integrating Psychology Into Church Ministry}

Our second research question explored the key barriers to integrating psychological science into church ministry. (See Table 5 for means and standard deviations of all items.) Overall, religious leaders indicated that the barriers moderately affected religious leaders from
Table 6

Hierarchical Regression Analysis Predicting

Perceived Barriers

\begin{tabular}{lccr}
\hline \multicolumn{1}{c}{ Predictor } & $\Delta R^{2}$ & $\beta$ & $s r^{2}$ \\
\hline Step 1 & .15 & & \\
$\quad$ Mainline protestant & & $-.33^{* *}$ & -.10 \\
$\quad$ Catholic & & $-.32^{* *}$ & -.09 \\
Step 2 & .22 & & \\
Mainline protestant & -.00 & -.00 \\
Catholic & -.01 & -.00 \\
Political conservatism & $.32^{* *}$ & .05 \\
Intratextual fundamentalism & $.31^{* *}$ & .04 \\
Religious intellectual humility & -.04 & -.00 \\
Emotional intelligence & $-.10^{*}$ & -.01 \\
\hline${ }^{*} p<.05 .{ }^{* *} p<.001$. & &
\end{tabular}

integrating psychological science into church ministry $(M=3.03 ; S D=0.81)$.

Regarding predictors of barriers, we used a hierarchical regression with barriers as the dependent variable. Denomination was entered as a predictor in Step 1 with evangelical protestant as the reference group. Political conservatism, intertextual fundamentalism, religious intellectual humility, and emotional intelligence were entered as predictors in Step 2.

Our hypothesis was partially supported (see Table 6). In Step 1, denomination predicted a significant amount of variance in perceived barriers $\left(R^{2}=.15, F(2,391)=33.48, p<.001\right)$. Catholic religious leaders reported a lower level of barriers $(M=2.73, S D=0.83)$ than did evangelical protestant religious leaders $(M=$ 3.32; $S D=0.70, \beta=.32, p<.001)$. Mainline protestant religious leaders also reported a lower level of barriers $(M=2.66, S D=0.77)$

Table 5

Perceived Barriers When Integrating Psychological Science and Christian Ministry

\begin{tabular}{lc}
\hline \multicolumn{1}{c}{ Barriers } & $M(S D)$ \\
\hline Lack of resources/funds & $3.28(1.17)_{\mathrm{a}}$ \\
Caution about potential secular/humanistic influence & $3.27(1.39)_{\mathrm{a}}$ \\
Need further training or information in this area & $3.25(1.13)_{\mathrm{a}}$ \\
Worldview differences & $3.20(1.27)_{\mathrm{a}, \mathrm{b}}$ \\
Too busy & $3.07(1.18)_{\mathrm{b}, \mathrm{c}, \mathrm{d}}$ \\
Value conflicts & $3.06(1.20)_{\mathrm{c}}$ \\
Incompatibility with church's theological beliefs & $3.00(1.40)_{\mathrm{c}}$ \\
Lack of biblical credibility & $2.90(1.40)_{\mathrm{d}}$ \\
Not relevant to church's mission & $2.26(1.17)_{\mathrm{e}}$ \\
\hline
\end{tabular}

Note. Different subscripts are significantly different from each other at $p<.05$. 
than did evangelical protestant religious leaders $(\beta=.33, p<.001)$.

In Step 2, the group of variables added a significant amount of variance in barriers over and above denomination $\left(\Delta R^{2}=.22, \Delta F(4\right.$, $387)=33.76, p<.001)$. In the final model, consistent with our hypotheses, both political conservatism $(\beta=.32, p<.001)$ and intratextual fundamentalism $(\beta=.31, p<.001)$ were significant positive predictors of perceived barriers, whereas emotional intelligence $(\beta=$ $-.10, p=.023$ ) was a significant negative predictor of barriers. Contrary to our hypotheses, in the final model, evangelical protestant religious leaders did not report significantly higher levels of barriers than mainline protestant religious leaders $(\beta=-.01, p=.884)$ or catholic religious leaders $(\beta=-.01, p=.866)$. Religious intellectual humility $(\beta=-.04, p=$ .380) was also not a significant predictor of perceived level of barriers.

\section{Compatibility Between Psychology and Church Ministry}

Our third research question explored church leaders' perceptions of the compatibility between psychological science and church ministry. (See Table 7 for means and standard deviations of all items.) Overall, religious leaders indicated that they perceived psychological science and church ministry as somewhat to very compatible $(M=3.75 ; S D=0.93)$.

Regarding predictors of compatibility between psychology and church ministry, we used a similar hierarchical regression analysis with compatibility as the dependent variable. Our

Table 7

Compatibility Between Psychological Science and Religion

\begin{tabular}{ll}
\hline \multicolumn{1}{c}{ Areas of compatibility } & $M(S D)$ \\
\hline Beliefs (i.e., What is true) about human & \\
$\quad$ nature & $4.00(1.03)_{\mathrm{a}}$ \\
Goals of spiritual care & $3.97(1.02)_{\mathrm{a}}$ \\
Values (i.e., What is important) & $3.89(1.01)_{\mathrm{b}}$ \\
Morals (i.e., What is right vs. wrong) & $3.78(1.10)_{\mathrm{c}}$ \\
Goals of Christian ministry & $3.76(1.07)_{\mathrm{c}}$ \\
Beliefs (i.e., What is true) about god & $3.51(1.22)_{\mathrm{d}}$ \\
Beliefs (i.e., What is true) about the bible & $3.37(1.12)_{\mathrm{e}}$ \\
\hline
\end{tabular}

Note. Different subscripts are significantly different from each other at $p<.05$.
Table 8

Hierarchical Regression Analysis Predicting

Perceived Compatibility

\begin{tabular}{lrrr}
\hline \multicolumn{1}{c}{ Predictor } & $\Delta R^{2}$ & $\beta$ & $s r^{2}$ \\
\hline Step 1 & .12 & & \\
Mainline protestant & & $.28^{* *}$ & .07 \\
Catholic & $.30^{* *}$ & .08 \\
Step 2 & .07 & & \\
Mainline protestant & .10 & .01 \\
Catholic & $.13^{*}$ & .01 \\
Political conservatism & $-.20^{*}$ & -.02 \\
Intratextual fundamentalism & $-.16^{*}$ & -.01 \\
Religious intellectual humility & & .03 & .00 \\
Emotional intelligence & & .04 & .00 \\
\hline
\end{tabular}

${ }^{*} p<.05 . \quad{ }^{* *} p<.001$.

hypothesis was partially supported (see Table 8). In Step 1, denomination predicted a significant amount of variance in compatibility between psychology and church ministry, $R^{2}=$ $.12, F(2,391)=25.58, p<.001)$. Catholic religious leaders reported higher compatibility $(M=4.10, S D=0.73)$ than did evangelical protestant religious leaders $(M=3.46 ; S D=$ $0.98, \beta=.30, p<.001)$. Mainline protestant religious leaders also reported higher compatibility $(M=4.09, S D=0.73)$ than did evangelical protestant religious leaders $(\beta=.28, p<$ .001).

In Step 2, the group of variables added a significant amount of variance in compatibility over and above denomination, $\Delta R^{2}=.07$, $\Delta F(4,387)=8.24, p<.001$. In the final model, evangelical protestant religious leaders reported significantly lower compatibility than catholic religious leaders $(\beta=.13, p=.034)$. Also, consistent with our hypotheses, political conservatism $(\beta=-.20, p=.004)$ and intratextual fundamentalism $(\beta=-.16, p=.034)$ were significant negative predictors of compatibility. However, in the final model, evangelical protestant religious leaders did not report significantly lower compatibility than mainline protestant religious leaders $(\beta=.10, p=.104)$. Furthermore, religious intellectual humility $(\beta=.03, p=.573)$ and emotional intelligence $(\beta=.04, p=.421)$ were not significant predictors of compatibility.

\section{Discussion}

Applied psychology and church ministry, despite sharing many goals, sometimes operate 
independently of one other. Although there has been an increase in the number of connection points between the two fields over the past couple of decades (e.g., research on religious/ spiritual coping as well as multicultural work emphasizing religion/spirituality as an important aspect of diversity), disconnection and mistrust between church ministry and psychology continue to persist. The present study aimed to explore religious leaders' current attitudes toward integrating psychological science and church ministry.

First, we examined the prevalence of various mental health/relational concerns and social/ community concerns that religious leaders observe in their congregations. Religious leaders from all denominations report that mental health/relational and social/community concerns were commonly seen in their congregations. These findings support prior research that has found that religious leaders are often on the front line of mental health treatment (Kloos et al., 1995). Furthermore, mainline religious leaders reported higher levels of social/community concerns than did evangelical protestant religious leaders. This may indicate that there is a higher prevalence of these concerns in mainline protestant churches. It may also be that mainline protestant religious leaders are more attuned or focused on social/community concerns than evangelical protestant religious leaders.

Second, we analyzed the perceived barriers religious leaders face when integrating psychological science into church ministry. The three most important barriers were (a) lack of resources and funds, (b) caution about potential secular/humanistic influence, and (c) need for further training or information. Thus, it may be that barriers tend to fall in one of three categories. First, religious leaders are busy and may not have time to delve into psychological research to explore how it might apply to their church ministry work. Second, there is concern that the values of psychology may not align or be compatible with the values of one's church. Third, church leaders may not be adequately trained to incorporate psychological science into their church ministry work.

There were some denominational differences in barriers (i.e., evangelical protestant religious leaders reported more barriers than mainline protestant or catholic religious leaders), but these differences became nonsignificant when the other predictors were entered into the model. Political conservatism and intratextual fundamentalism were associated with more barriers, whereas emotional intelligence was associated with fewer barriers. This finding suggests that religious leaders who are politically conservative and hold the Bible as more sacred and central are more likely to identify barriers to utilizing psychological science in their ministry work. This separation between psychological science and church ministry may be rooted in fundamentalists' historical reaction against modern science (Marsden, 2006). The results from the present study also suggest that emotional intelligence is associated with lower hesitancy to engage with psychological science. Having a greater scientific and theological understanding of emotions, particularly surrounding mental health and social/community concerns, may encourage religious leaders to engage with the psychological community to discover practical ways to support and provide aid to their congregants.

Third, we examined the perceived compatibility between psychological science and church ministry among religious leaders. There were some denominational differences in compatibility (e.g., Catholic and Mainline Protestant religious leaders reported higher levels of compatibility than Evangelical Protestant religious leaders). Contrary to our initial hypothesis, Mainline Protestant religious leaders did not report higher levels of compatibility than Catholic religious leaders. Political conservatism and intratextual fundamentalism also correlated negatively with compatibility. These findings support the notion that more conservative religious leaders may view psychology and church ministry as less compatible, perhaps because psychology is strongly influenced by liberal political values and social justice concerns. This finding is also consistent with past research that has discovered feelings of mistrust between religion and psychology (McMinn et al., 1998) that are largely shaped by differences in political values.

\section{Limitations and Suggestions for Future Research}

There were several limitations to the present study. First, the study used a cross-sectional, correlational design. Thus, causal conclusions 
should not be made. Although many of the variables analyzed were significant predictors of attitudes toward integrating psychology and church ministry, there may be other unmeasured variables that explain this relationship. For example, religious leaders that have had more exposure to psychological science through undergraduate or graduate education in a psychology-related field may be more open to utilizing this knowledge in their ministries. Longitudinal or experimental research is necessary to further explain a religious leader's openness to using psychological science in their ministry.

Second, the measures used in the current study were self-report measures, some of which were specifically created for the present study. Self-report measures have several limitations (e.g., socially desirable responding), and the measures that were specifically created for the study lack prior evidence of reliability and validity. Therefore, future studies could explore the possibility of using alternative measures to gather information regarding church leaders' use/perspective of psychological science, such as examination of sermon notes or ministry curriculum.

Third, the participants in the current study were mostly white and male. Future research should examine other types of religious leaders, specifically samples of racially/ethnically diverse participants and female church leaders to see whether certain groups are more likely to utilize psychological science within their ministries and why this may be. Furthermore, data were not collected to determine whether there were differences between leaders who participated in the study and leaders who did not participate. Future research may benefit from better understanding why some religious leaders choose to participate in scientific studies whereas others do not.

\section{Practical Application}

Our findings suggest that there are certain factors that religious leaders and psychological researchers should be aware of to (a) improve communication between these two fields and (b) provide greater access of mental health services to the general public. First, religious leaders and psychological researchers should be aware of the important role that political orientation plays in church leaders' attitudes toward psychological science. For psychologists and ministers to work together, it may take some degree of political alignment. For example, politically conservative psychologists may be in a unique position to collaborate with ministers who hold a similar political perspective, particularly evangelical church leaders. On the other hand, more progressive psychologists may be more successful in collaborating with catholic or mainline protestant clergy. If psychologists and church leaders are far apart on political values, it may be necessary for both parties to be high in cultural humility (Hook et al., 2013) and develop a superordinate goal in order to collaborate together. It is also likely that development of the personal relationship and trust between psychologists with church leaders is necessary for meaningful collaboration to occur.

Second, religious leaders and psychological researchers should also be aware of the role intratextual fundamentalism plays in one's attitudes toward psychological science. It is likely that collaboration with clergy who are high in intratextual fundamentalism may look different and require flexibility on the part of psychologists. As fundamentalism originated as a reaction against modernism (Barr, 1977), the task of engaging church leaders high in intratextual fundamentalism may feel similar to crossing a cultural barrier or developing a common language with those who are culturally different. It is possible that some religious leaders may feel defensive toward any literature that is not based on the Bible. Therefore, presenting psychological findings in a way that encourages religious leaders to evaluate psychological findings alongside their sacred text may allow religious leaders to be more open to psychology and see the two fields as more compatible. For example, psychologists and religious leaders could explore how various research findings from psychological science are in alignment (or not) with a religious leader's sacred text. The religious leader may then feel more comfortable integrating the findings from psychological science that are in alignment with the values and teachings of their sacred text.

Third, our findings explored the most prevalent mental health/relational and social/community concerns that religious leaders currently face. To increase communication between church ministry and psychological science, it 
would be beneficial for researchers to provide specific resources for church leaders to help provide care for the individuals in their churches. There are some programs that have been developed to help church members receive mental health treatment and support (e.g., Celebrate Recovery, Grief Share). Because church ministry is often the initial contact for individuals seeking mental health treatment (Kloos et al., 1995), developing programs or resources to be utilized within churches could allow for mental health treatment to be available to a greater number of individuals in need. Furthermore, another goal to consider is helping ministers and parishioners explore the scientific basis for the interventions they are seeking. Many church leaders refer their parishioners to intervention programs or mental health professionals when they do not feel equipped to handle a particular issue. Having a greater understanding of the scientific basis for these interventions will not only help church leaders discern which referrals to make, but it may also inform church leaders about psychological science regarding topics that are being considered for future sermons.

\section{Conclusion}

We encourage psychology researchers to recognize the important role that religion plays in many individuals' lives. A religious individual's connection to their church may be their primary avenue of discussing various mental health/relational and social/community concerns (Allen \& Hill, 2014; Veroff et al., 1981). Our findings suggest that many religious leaders continue to believe that church ministry and psychological science are incompatible. Accordingly, it is important for researchers to discover better ways of communicating psychological findings with religious leaders in a way that instills trust. We encourage psychologists to draw on the rich resources within multicultural and community psychology to expand the potential populations that trust psychology to respect their worldview and meet their mental health needs.

\section{References}

Allen, G. E. K., \& Hill, C. (2014). Exploring perceived attitudes of counseling between LDS reli- gious leaders and mental health therapists. Religion and Psychotherapy, 36, 71-82.

Barr, J. (1977). Fundamentalism. Philadelphia, PA: The Westminster Press.

Baucom, D. H., Shoham, V., Mueser, K. T., Daiuto, A. D., \& Stickle, T. R. (1998). Empirically supported couple and family interventions for marital distress and adult mental health problems. Journal of Consulting and Clinical Psychology, 66, 53-88. http://dx.doi.org/10.1037/0022-006X.66.1.53

Baumeister, R. F., \& Vohs, K. D. (2004). Selfregulation. In C. Peterson \& M. E. P. Seligman (Eds.), Character strengths and virtues: A handbook and classification (pp. 499-516). Washington, DC/New York, NY: American Psychological Association/Oxford Press.

Benes, K. M., Walsh, J. M., McMinn, M. R., Dominguez, A. W., \& Aikins, D. C. (2000). Psychology and the church: An exemplar of psychologistclergy collaboration. Professional Psychology: Research and Practice, 31, 515-520. http://dx.doi .org/10.1037/0735-7028.31.5.515

Brown, A. E., Tonigan, J. S., Pavlik, V. N., Kosten, T. R., \& Volk, R. J. (2013). Spirituality and confidence to resist substance use among celebrate recovery participants. Journal of Religion and Health, 52, 107-113. http://dx.doi.org/10.1007/ s10943-011-9456-x

Burford, J. D. (2005). Assessing recovery tools for use by the church in helping male users of pornography. Unpublished doctoral dissertation, Biola University, La Mirada, CA.

Captari, L. E., Hook, J. N., Hoyt, W., Davis, D. E., McElroy-Heltzel, S. E., \& Worthington, E. L., Jr. (2018). Integrating clients' religion and spirituality within psychotherapy: A comprehensive metaanalysis. Journal of Clinical Psychology, 74, 1938-1951. http://dx.doi.org/10.1002/jclp.22681

Chaddock, T. P., \& McMinn, M. R. (1999). Values affecting collaboration among psychologists and evangelical clergy. Journal of Psychology and Theology, 27, 319-328. http://dx.doi.org/10.1177/ 009164719902700404

Chalfant, H. P., Heller, P. L., Roberts, A., Briones, D., Aguirre-Hochbaum, S., \& Farr, W. (1990). The clergy as a resource for those encountering psychological distress. Review of Religious Research, 31, 305-313. http://dx.doi.org/10.2307/3511620

Cooper, A., \& Petrides, K. V. (2010). A psychometric analysis of the Trait Emotional Intelligence Questionnaire-Short Form (TEIQue-SF) using item response theory. Journal of Personality Assessment, 92, 449-457. http://dx.doi.org/10.1080/ 00223891.2010 .497426

Cornish, J. A. E., Schreier, B. A., Nadkarni, L. I., Metzger, L. H., \& Rodolfa, E. R. (Eds.). (2010). Handbook of multicultural counseling competencies. Hoboken, NJ: Wiley. 
Davis, D. E., Worthington, E. L., Jr., \& Hook, J. N. (2010). Humility: Review of measurement strategies and conceptualization as a personality judgment. The Journal of Positive Psychology, 5, 243-252. http:// dx.doi.org/10.1080/17439761003791672

Delaney, H. D., Miller, W. R., \& Bisono, A. M. (2013). Religiosity and spirituality among psychologists: A survey of clinical members of the American Psychological Association. Spirituality in Clinical Practice, 1, 95-106. http://dx.doi.org/ 10.1037/2326.4500.1.S.95

Duarte, J. L., Crawford, J. T., Stern, C., Haidt, J., Jussim, L., \& Tetlock, P. E. (2015). Political diversity will improve social psychological science. Behavioral and Brain Sciences, 38, e130.

Edwards, L. C., Lim, B. R. K. B., McMinn, M. R., \& Dominguez, A. W. (1999). Examples of collaboration between psychologists and clergy. Professional Psychology: Research and Practice, 30, 547-551. http://dx.doi.org/10.1037/0735-7028.30 .6 .547

Emmons, R. A., \& McCullough, M. E. (2003). Counting blessings versus burdens: An experimental investigation of gratitude and subjective wellbeing in daily life. Journal of Personality and Social Psychology, 84, 377-389. http://dx.doi.org/ 10.1037/0022-3514.84.2.377

FitzGerald, F. (2017). The evangelicals: The struggle to shape America. New York, NY: Simon \& Schuster.

Freud, S. (1961). The future of an illusion. In J. Strachey (Ed. \& Trans.), The standard edition of the complete psychological works of Sigmund Freud (Vol. 21, pp. 1-56). London, UK: Hogarth Press and the Institute of Psycho-Analysis. (Original work published 1927)

Gorsuch, R. L., \& Meylink, W. D. (1988). Toward a co-professional model of clergy-psychologist referral. Journal of Psychology and Christianity, 7, 22-31.

Graham, J., Haidt, J., \& Nosek, B. A. (2009). Liberals and conservatives rely on different sets of moral foundations. Journal of Personality and Social Psychology, 96, 1029-1046. http://dx.doi.org/ 10.1037/a0015141

Hadaway, C. K., \& Marler, P. L. (2006). Growth and decline in the mainline. In C. H. Lippy (Ed.), Faith in America: Changes, challenges, and new directions (Vol. 1, pp. 1-24). Westport, CT: Praeger.

Hood, R. W., Jr., Hill, P. C., \& Williamson, W. P. (2005). The psychology of religious fundamentalism. New York, NY: Guilford Press.

Hook, J. N., Davis, D. E., Owen, J., Worthington, E. L., Jr., \& Utsey, S. O. (2013). Cultural humility: Measuring openness to culturally diverse clients. Journal of Counseling Psychology, 60, 353-366. http://dx.doi.org/10.1037/a0032595
Hook, J. N., Davis, D. E., Van Tongeren, D. R., Hill, P. C., Worthington, E. L., Jr., Farrell, J. E., \& Dieke, P. (2015). Intellectual humility and forgiveness of religious leaders. The Journal of Positive Psychology, 10, 499-506. http://dx.doi.org/10 $.1080 / 17439760.2015 .1004554$

Hook, J. P., Hook, J. N., \& Davis, D. E. (2017). Helping groups heal: Leading small groups in the process of transformation. West Conshohocken, PA: Templeton Press.

Hook, J. N., Worthington, E. L., Jr., \& Davis, D. E. (2012). Religion and spirituality in counseling. In N. A. Fouad, J. A. Carter, \& L. M. Subich (Eds.), APA handbooks in psychology: APA handbook of counseling (Vol. 2, pp. 417-432). Washington, DC: American Psychological Association.

Hook, J. N., Worthington, E. L., Jr., Davis, D. E., Gartner, A. L., Jennings, D. J., II, \& Hook, J. P. (2010). Empirically supported religious and spiritual therapies. Journal of Clinical Psychology, 66, 46-72.

Hook, J. N., Worthington, E. L., Jr., Hook, J. P., Miller, B. T., \& Davis, D. E. (2011). Marriage matters: A description and initial evaluation of a church-based marital education program. Pastoral Psychology, 60, 869-875. http://dx.doi.org/10 .1007/s11089-011-0398-8

Inbar, Y., \& Lammers, J. (2012). Political diversity in social and personality psychology. Perspectives on Psychological Science, 7, 496-503. http://dx.doi .org/10.1177/1745691612448792

Jakubowski, S. F., Milne, E. P., Brunner, H., \& Miller, R. B. (2004). A review of empirically supported marital enrichment programs. Family Relations, 53, 528-536. http://dx.doi.org/10.1111/j .0197-6664.2004.00062.x

James, W. (1985). The varieties of religious experience: A study in human nature. Cambridge, MA: Harvard University Press. (Original work published 1902)

Johnson, K. A., Hook, J. N., Davis, D. E., Van Tongeren, D. R., Sandage, S. J., \& Crabtree, S. A. (2016). Moral foundation priorities reflect U.S. Christians' individual differences in religiosity. Personality and Individual Differences, 100, 5661. http://dx.doi.org/10.1016/j.paid.2015.12.037

Jung, C. G. (1968). Concerning the archetypes, with special reference to the anima concept. In H. Read, M. Fordham, \& G. Alder (Eds.), The collected works of C. G. Jung (2nd ed., Vol. 9, Part I (pp. 54-72). Princeton, NJ: Princeton University Press. (Original work published 1954)

Kloos, B., Horneffer, K., \& Moore, T. (1995). Before the beginning: Religious leaders' perceptions of the possibility for mutually beneficial collaboration with psychologists. Journal of Community Psychology, 23, 275-291. http://dx.doi.org/ 
10.1002/1520-6629(199510)23:4<275::AIDJCOP2290230402>3.0.CO;2-U

Koenig, H. G., King, D. E., \& Carson, V. B. (2012). Handbook of religion and health (2nd ed.). New York, NY: Oxford University Press.

Laborde, S., Allen, M. S., \& Guillén, F. (2016). Construct and concurrent validity of the short- and long- form versions of the trait emotional intelligence questionnaire. Personality and Individual Differences, 101, 232-235. http://dx.doi.org/10 .1016/j.paid.2016.06.009

Lilienfeld, S. O. (2007). Psychological treatments that cause harm. Perspectives on Psychological Science, 2, 53-70. http://dx.doi.org/10.1111/j .1745-6916.2007.00029.x

Lish, R. A., McMinn, M. R., Fitzsimmons, C. R., \& Root, A. M. (2003). Clergy interest in innovative collaboration with psychologists. Journal of Psychology and Christianity, 22, 294-298.

Marsden, G. M. (2006). Fundamentalism and American culture (2nd ed.). New York, NY: Oxford University Press.

Mayer, J. D., Roberts, R. D., \& Barsade, S. G. (2008). Human abilities: Emotional intelligence. Annual Review of Psychology, 59, 507-536. http:// dx.doi.org/10.1146/annurev.psych.59.103006 .093646

McCage, S. V., II. (2003). The effectiveness of DivorceCare on divorce adjustment and spiritual well-being. Unpublished doctoral dissertation, Southwestern Baptist Theological Seminary, Fort Worth, TX.

McMinn, M. R., Chaddock, T. P., Edwards, L. C., Lim, B. R. K. B., \& Campbell, C. D. (1998). Psychologists collaborating with clergy. Professional Psychology: Research and Practice, 29, 564-570. http://dx.doi.org/10.1037/0735-7028.29 .6 .564

McMinn, M. R., Meek, K. R., Canning, S. S., \& Pozzi, C. F. (2001). Training psychologists to work with religious organizations: The center for church-psychology collaboration. Professional Psychology: Research and Practice, 32, 324-328. http://dx.doi.org/10.1037/0735-7028.32.3.324

Miller, W. R., \& Thoresen, C. E. (2003). Spirituality, religion, and health. An emerging research field. American Psychologist, 58, 24-35. http://dx.doi .org/10.1037/0003-066X.58.1.24

Newberry, D. E., \& Tyler, J. D. (1997). Mental health value differences between psychologists and clergy. Counseling and Values, 41, 155-158. http://dx .doi.org/10.1002/j.2161-007X.1997.tb00397.x

Petrides, K. V. (2009). Psychometric properties of the Trait Emotional Intelligence Questionnaire. In C. Stough, D. H. Saklofske, \& J. D. Parker (Eds.), Assessing emotional intelligence: Theory, research, and applications (pp. 85-101). New York,
NY: Springer. http://dx.doi.org/10.1007/978-0387-88370-0_5

Piedmont, R. L. (2009). Editorial. Psychology of Religion and Spirituality, 1, 1-2. http://dx.doi.org/10 $.1037 / \mathrm{a} 0015253$

Randall, K. J. (2014). Emotional intelligence: What is it, and do Anglican clergy have it? Mental Health, Religion \& Culture, 17, 262-270. http:// dx.doi.org/10.1080/13674676.2013.796916

Savage, S. B. (2003). Psychology serving the church in the United Kingdom: Church consultancy and pastoral care. Journal of Psychology and Christianity, 22, 338-342.

Seligman, M. E. P., \& Csikszentmihalyi, M. (2000). Positive psychology. An introduction. American Psychologist, 55, 5-14. http://dx.doi.org/10.1037/ 0003-066X.55.1.5

Shafranske, E. P., \& Malony, H. N. (1990). Clinical psychologists' religious and spiritual orientations and their practice of psychotherapy. Psychotherapy: Theory, Research, Practice, Training, 27, 7278. http://dx.doi.org/10.1037/0033-3204.27.1.72

Skinner, B. F. (1953). Science and human behavior. New York: Macmillan.

Sue, D. W., Arredondo, P., \& McDavis, R. J. (1992). Multicultural counseling competencies and standards: A call to the profession. Journal of Counseling \& Development, 70, 477-486. http://dx.doi .org/10.1002/j.1556-6676.1992.tb01642.x

Sue, D. W., Bernier, Y., Durran, A., Feinberg, L., Pedersen, P. B., Smith, E. J., \& Vasquez-Nuttal, E. (1982). Position paper: Cross-cultural counseling competencies. The Counseling Psychologist, 10, 4552. http://dx.doi.org/10.1177/0011000082102008

Terry, J. D., Smith, A. R., Warren, P. R., Miller, M. E., McQuillin, S. D., Wolfer, T. A., \& Weist, M. D. (2015). Incorporating evidence-based practices into faith-based organization service programs. Journal of Psychology and Theology, 43, 212-223. http://dx.doi .org/10.1177/009164711504300306

Thompson, C. C. (1988). A descriptive study of the impact of a church-based support group on individuals experiencing grief. Unpublished doctoral dissertation, University of Pittsburgh, Pittsburgh, PA.

Vera, E. M., \& Speight, S. L. (2003). Multicultural competence, social justice, and counseling psychology: Expanding our roles. The Counseling Psychologist, 31, 253-272. http://dx.doi.org/10 $.1177 / 0011000003031003001$

Veroff, J., Kulka, R. A., \& Douvan, E. (1981). Mental health in America: Patterns of help-seeking from 1957-1976. New York, NY: Basic Books.

Wade, N. G., Hoyt, W. T., Kidwell, J. E. M., \& Worthington, E. L., Jr. (2014). Efficacy of psychotherapeutic interventions to promote forgiveness: A meta-analysis. Journal of Consulting and Clin- 
ical Psychology, 82, 154-170. http://dx.doi.org/10 $.1037 / \mathrm{a} 0035268$

Walker, D. F., Gorsuch, R. L., Tan, S. Y., \& Otis, K. E. (2008). Use of religious and spiritual interventions by trainees in APA-accredited Christian clinical psychology programs. Mental Health, Religion \& Culture, 11, 623-633. http://dx.doi.org/ 10.1080/13674670701867648

Wilde, M., \& Glassman, L. (2016). How complex religion can improve our understanding of American politics. Annual Review of Sociology, 42, 407-425. http://dx.doi.org/10.1146/annurev-soc081715-074420

Williamson, W. P., Hood, R. W., Jr., Ahmad, A., Sadiq, M., \& Hill, P. C. (2010). The Intratextual Fundamentalism Scale: Cross-cultural application, validity evidence, and relationship with religious orientation and the Big 5 factor markers. Mental
Health, Religion \& Culture, 13, 721-747. http:// dx.doi.org/10.1080/13674670802643047

Woodruff, E., Van Tongeren, D. R., McElroy, S., Davis, D. E., \& Hook, J. N. (2014). Humility and religion: Benefits, difficulties, and a model of religious tolerance. In C. Kim-Prieto (Ed.), Positive psychology of religion and spirituality across cultures (pp. 271-285). New York, NY: Springer. http://dx.doi.org/10.1007/978-94-017-8950-9_14

Yarhouse, M. A., McRay, B. W., \& Butman, R. E. (2016). Modern psychopathologies: A comprehensive Christian appraisal (2nd ed.). Downer's Grove, IL: InterVarsity Press. 